\title{
IMPACT OF SOME BIOAGENT AND INSECT GROWTH REGULATOR TO SOME BIOCHEMICAL ASPECTS OF THE COTTON LEAF WORM, SPODOPTERA LITTORALIS (BOISD.)
}

\author{
ABDEL-SALAM, A. H.1; AMAL M. MABROUK ${ }^{2}$; \\ HALA A.K. EL-SERAFY ${ }^{1}$ and NEVEN M. FAIZ ${ }^{2}$
}

\author{
${ }^{1}$ Economic Entomology Department, Faculty of Agriculture, Mansoura University, \\ Mansoura 35516, EGYPT \\ ${ }^{2}$ Plant Protection Research Institute, Agricultural Research Center, Ministry of \\ Agriculture \\ E-mail: adhabdel@gmail.com
}

(Manuscript received 24 April 2018)

\begin{abstract}
$\mathrm{T}$ his experiment was conducted on the $4^{\text {th }}$ instars larvae of Spodoptera littoralis to investigate the effect of Protecto, Viruset, Cascade, and Atabron. The effect of the tested compounds on the total protein, total carbohydrate, and total lipids were determined in the $6^{\text {th }}$ instars larvae. After treatment the $4^{\text {th }}$ instars larvae results showed that the treatment of the $4^{\text {th }}$ instar larvae with the $\mathrm{LC}_{50}$ of the tested compounds represented a significant decrease in the amount of total protein, total carbohydrate, and total lipid. Therefore, biopesticides can be used as safe substitutes for chemical insecticides a they have influenced the formation of tissues of treated insects.

Key Words: Bioagent, Insect Growth Regulator (IGR), Biochemical aspects, Spodoptera littoralis
\end{abstract}

\section{INTRODUCTION}

The Egyptian cotton leaf worm, Spodoptera littoralis (Boisd.), is an important pest in Egypt and other countries in Africa and Asia. It causes destructive and extensive economic losses in many cultivated crops (Frank et al., 1990). The problems and hazards that have arisen as a result of using conventional insecticides were incentives for the search of alternative control agents. Microbial pest control agents are a primary means of biological control for insect pests. The use of microbial control agents is targeted for a particular pest species. The entomopathogens have most been used in biological control include representatives of bacteria, fungi, viruses, nematodes, protozoa and insect growth regulator (Dent, 2000).

Since the discovery of the microbial insecticide, Bacillus thuringiensis (Bt), it has been widely used to control insect pests in agriculture, forestry and medicine. It was primarily used as environmentally safe, alternative, conventional and commercial insecticides. The effects of various commercial products on life cycle aspects as well as growth potential of the pests area promising alternative for insect biocontrol in Egypt (Abd El-Salam et al., 2011). 
Baculoviruses, among other insect viruses, are regarded as other safe and selective bio-insecticides, restricted to invertebrates. They have been used worldwide against many insect pests, mainly Lepidoptera. Problems that have limited expansion of baculovirus use include narrow host range, slow killing speed, technical and economic difficulties (Moscardi, 1999). Investigations on the effect of combining sublethal doses of baculovirus isolates and $B t$ strains on lepidopterous insects showed variable effects, ranging from antagonistic to additive effects (Mabrouk, 2001).

The use of the insect growth regulators (IGR's) for the control of insects of economic importance have been widely acclaimed, either as juvenile or ecdysone hormone mimics, chitin synthesis inhibitor or other compounds (Smagghe and Degheele, 1992 and Smagghe et al., 1995). These compounds interfere with the normal growth or development of insects and their effect could extend to affect the insect's reproductive potential as well as other effects on the physiology of treated insects (Abdel-Wahed et al., 2011 and Abdel-Aziz, 2012). The present study is an extension of previous studies which dealt with the effects of certain bioagents and IGRs on some metabolic parameters in the contton leafworm, Spodoptera littoralis (Boisduval). The current investigation was particularly conducted to evaluate the latent effect of tested bioagents and IGRs on the total lipids, total proteins, and total carbohydrates as main components of insect tissues and organs.

\section{MATERIALS AND METHODS}

\section{Rearing of S. littoralis (Boisd):}

The culture of the cotton leafworm, S. littoralis (Boisd) was initiated from freshly collected eggs masses supplied from the division of cotton leafworm of plant protection research Institute, Dokki, Egypt, formed the basis of the culture designed to provide insects used in the present work. All stages of $S$. littoralis were cultured and tested at $27 \pm 2^{\circ} \mathrm{C}$ and $70 \pm 5 \%$ R.H. Larval stages were reared on caster bean leaves which were provided daily. The formed pupae were collected and placed in clean Jars with moist saw dust placed at the base to provide the pupation site. Adults were provided with $10 \%$ sugar solution.

\section{Toxicological studies:}

Second and fourth instar larvae were treated separately. Five replicates each containing 10 larvae was tested using leaf-dipping technique (Tabashnik et al., 1991). Fresh and clean castor leaves were immersed for 10 seconds in the prepared suspensions of the compounds under test. The treated leaves were then left to dry at room temperature before being offered to the test larvae. 
For the control experiment, the same numbers of larvae were offered fresh clean castor leaves dipped in distilled water. Mortality was recorded daily and cumulative larval mortality was determined at the end of the larval stage.

\section{Biochemical studies:}

For biochemical analysis, thirty healthy and treated as $4^{\text {th }}$ larval instars with LC 50 of tested compound, Protecto, Viruset, Cascade, and Atabron, $6^{\text {th }}$ larval instars were weighted and kept under freezing conditions at $-20^{\circ} \mathrm{C}$.

\section{Sample Preparation:}

One gram of larvae at the $6^{\text {th }}$ larval instar that were treated as $4^{\text {th }}$ instar larvae with LC50 of tested compounds and survived treatment were weighed. These larvae were then homogenized in physiological saline solution $(\mathrm{NaCl} 8.8 \mathrm{~g} ., \mathrm{KCl} 0.2$ g., and $\mathrm{CaCl}_{2} 0.3 \mathrm{~g}$./liter, $\mathrm{PH}$ 6.7-6.8) with traces of phenylthiourea crystals using a glass homogenizer for $3 \mathrm{~min}$. Control specimen was obtained by homogenizing healthy larvae through the same technique. Homogenates were centrifuged at 8000 r.p.m. for $15 \mathrm{~min}$. The supernatant was used directly or stored at $-20^{\circ} \mathrm{C}$ until needed for biochemical determination. All the biochemical determinations were done at pest physiology department, plant protection research institute, A.R.C., Egypt.

\section{Total proteins}

Total proteins were determined by the method of Bradford (1976). Protein reagent was prepared by dissolving $100 \mathrm{mg}$. of Coomassie Brilliant Blue G-250 in 50 ml. $95 \%$ ethanol. Solution of $100 \mathrm{ml} .85 \%$ (w/v) phosphoric acid were added. The resulting solution was diluted to a final volume of 1 liter. Sample solution $(50 \mu \mathrm{l})$ for preparation of standard curve $50 \mu \mathrm{l}$ of serial concentrations containing 10 to $100 \mu \mathrm{g}$ bovin serum albumin were pipetted into test tubes. The volume in the test tube was adjusted to $0.1 \mathrm{ml}$. with phosphate buffer (PH 6.6). 5 millimeters of protein reagent were added to test tube and the contents were mixed either by inversion or vortexing. The absorbance at $595 \mathrm{~nm}$. was measured after $2 \mathrm{~min}$. and before 1h. against blank prepared from $0.1 \mathrm{ml}$ of phosphate buffer $(\mathrm{PH} \mathrm{6.6)}$ ) and $5 \mathrm{ml}$. of protein reagent. Total protein was expressed as $\mathrm{mg} / \mathrm{g}$. b.w.

\section{Total carbohydrates:}

Total carbohydrates were estimated in acid extract of the sample by the phenol-sulphuric acid reaction of Dubois, et al. (1956). Total carbohydrates were extracted from the sample and prepared for assay according to Crompton and Birt (1967). Sample was homogenized in $0.3 \mathrm{~N} \mathrm{HClO}_{4}(5 \mathrm{ml}$.$) at 0^{\circ} \mathrm{C}$ for $1 \mathrm{~min}$. The homogenate was kept in ice for further $10 \mathrm{~min}$. Insoluble matter was removed by centrifugation for $3 \mathrm{~min}$ at 2000 r.p.m and washed twice in ice cold $\mathrm{HClO}_{4}(5 \mathrm{ml})$ by redispertion and centrifugation. The three supernatant combined into acid extract. 
Hundred microliters of the acid extract were added into a colorimetric tube to $0.5 \mathrm{ml}$. of phenol (20 percent $\mathrm{w} / \mathrm{v}$ ). Then $5 \mathrm{ml}$. of concentrated sulfuric acid were added rapidly with shaking. The tubes were allowed to stand $10 \mathrm{~min}$., and then they were shaken and placed for $10-20 \mathrm{~min}$ in water bath at 25 to $30^{\circ} \mathrm{C}$. before reading. Blanks were prepared by substituting distilled water for the sugar solution. The absorbance of characteristic yellow-orange color is measured at $490 \mathrm{~nm}$ against blank. Total carbohydrate is expressed as $\mu \mathrm{g}$ glucose/gm fresh weight.

\section{Total lipids:}

Total lipids were estimated by the method of Knight, et al. (1972) using phosphovanillin reagent prepared by dissolving of $0.6 \mathrm{gm}$. pure vanillin in $10 \mathrm{ml}$. ethanol and completed to $100 \mathrm{ml}$. with distilled water. Then $400 \mathrm{ml}$ conc. Phosphoric acid was added. $250 \mu \mathrm{l}$ of sample were added to conc. Sulphuric acid $(5 \mathrm{ml}$.) in a test tube and heated in a boiling water bath for $10 \mathrm{~min}$. After cooling to room temperature, the digest was added to phosphovanillin reagent (6 ml.). After 45 min., the devolved color was measured at $525 \mathrm{~nm}$. against reagent blank. Optical density was compared to that of a reference standard and results expressed as mg. lipids/ml. heamolymph.

\section{RESULTS AND DISCUSSION}

\section{Bioassay test:}

Data in table (1) showed larval mortality rates due to treatment of the $2^{\text {nd }}$ and $4^{\text {th }}$ larval instars with different concentrations of the used bioinsecticides and the IGRs. $\mathrm{LC}_{25}, \mathrm{LC}_{50}$, and $\mathrm{LC}_{90}$ values were determined for both $2^{\text {nd }}$ and $4^{\text {th }}$ larval instars. Protecto exhibited a high toxic effect than the viruset.

Atabron was the most toxic compound in all tested compounds, evidenced by the very low $L_{25}$, $L C_{50}$, and $L C_{90}$ values. The tested bioagents did not result in instant mortality, however, mortality rates increased at the end of the larval stage. The $2^{\text {nd }}$ larval instar was more susceptible to all tested compounds than the $4^{\text {th }}$ larval instar. Table 1 . Susceptibility of the cotton leaf worm, Spodoptera littoralis, to tested compounds

\begin{tabular}{|c|c|c|c|c|c|}
\hline $\begin{array}{c}\text { Tested } \\
\text { Compounds }\end{array}$ & $\begin{array}{c}\text { Larval } \\
\text { instar }\end{array}$ & $\begin{array}{c}\mathbf{L C}_{\mathbf{2 5}} \\
\mathbf{( g m / \mathbf { m l } )}\end{array}$ & $\begin{array}{c}\mathbf{L C}_{\mathbf{5 0}} \\
\mathbf{( g m / \mathbf { m l } )}\end{array}$ & $\mathbf{L C}_{\mathbf{9 0}} \mathbf{( g m / \mathbf { m l } )}$ & Slope $\pm \mathbf{S . E . ~}$ \\
\hline \multirow{2}{*}{ Protecto } & $\mathbf{2}^{\text {nd }}$ & $8.7 \times 10^{-8}$ & $1.7 \times 10^{-5}$ & 0.418 & $0.29 \pm 0.0297$ \\
\cline { 2 - 6 } & $\mathbf{4}^{\text {th }}$ & $1.4 \times 10^{-8}$ & $2 \times 10^{-5}$ & 1.98 & $0.21 \pm 0.0225$ \\
\hline \hline \multirow{2}{*}{ Viruset } & $\mathbf{2}^{\text {nd }}$ & $4.8 \times 10^{-9}$ & $1.1 \times 10^{-5}$ & 2.34 & $0.20 \pm 0.0252$ \\
\cline { 2 - 6 } & $\mathbf{4}^{\text {th }}$ & $4.7 \times 10^{-7}$ & $1 \times 10^{-4}$ & 3.134 & $0.29 \pm 0.0315$ \\
\hline \hline \multirow{2}{*}{ Atabron } & $\mathbf{2}^{\text {nd }}$ & $0.43 \times 10^{-11}$ & $0.3 \times 10^{-5}$ & $0.68 \times 10^{-5}$ & $1.35 \pm 0.118$ \\
\cline { 2 - 6 } & $\mathbf{4}^{\text {th }}$ & $0.83 \times 10^{-5}$ & $1.06 \times 10^{-6}$ & $1.68 \times 10^{-6}$ & $1.45 \pm 0.2001$ \\
\hline \hline \multirow{2}{*}{ Cascade } & $\mathbf{2}^{\text {nd }}$ & $0.2 \times 10^{-8}$ & $0.12 \times 10^{-8}$ & $0.64 \times 10^{-7}$ & $0.025 \pm 0.001$ \\
\cline { 2 - 6 } & $\mathbf{4}^{\text {th }}$ & $0.4 \times 10-8$ & $0.16 \times 10^{-8}$ & $0.387 \times 10^{-6}$ & $2.45 \pm 0.222$ \\
\hline
\end{tabular}


Effect of treatment of the $4^{\text {th }}$ larval instar with $\mathrm{LC}_{50}$ of bioinsecticides and IGRs on (total carbohydrates, total protein and total lipids) is shown in tables (2).

Results given in Table (2) indicated that all tested insecticides led to decrease in total carbohydrates which more obvious with Atabron, compared with control. Total carbohydrates content were $41.2 \pm 0.80,40.06 \pm 0.6,40.33 \pm 0.6$ and $39.36 \pm$ 0.39 (mg/g.b.wt) for Protecto, Viruset, Cascade, and Atabron, respectively, while it was $44.2 \pm 0.7 \quad$ (mg/g.b.wt) with control.

Obtained results showed that the total protein content of $S$. littoralis $6^{\text {th }}$ instar larvae treated as $4^{\text {th }}$ instar larvae were decreased in all tested compounds. The total protein were $48.6 \pm 1.5,56.6 \pm 1.3,69.63 \pm 0.6$ and $60.73 \pm 0.8$ (mg/g.b.wt) with Protecto, Viruset, Cascade and Atabron, respectively, compared with control $75.7 \pm$ 2.05 (mg/g.b.wt).

All used compounds was caused significantly decrease in the total lipids, Cascade was the most effective compound (37.73 \pm 1.37 ), followed by Viruset, (38.36 \pm 0.79 ), Protecto, $(38.9 \pm 0.6$ ) finally Atabron (39.06 \pm 0.475$)$, compared with control $(44.26 \pm 2.84)$.

These results are in harmony with those obtained by Anwar and Abd ElMageed (2005) and Abdel-Ghany (2011) who found that reduction in carbohydrate content, total lipid and total protein of $S$. littoralis larvae when treated with castor oil, gossypol, diflubenzuron, tebufenozide, hexaflumuron, flufenoxuron, chlorfluazuron and lufenuron. Similarly Abou Zeid (1998) on Ostrinia nubilalis (Hübner) larvae, Shaurub et al. (1998) on ovarioles of S. littoralis and Sundari (1998) on Euproctis fraternal (Moore) who observed a significant reduction in carbohydrates content when treated with Piper nigrum L., respectively.

The obtained results also are in agreement with the results of Kamel et al. (2010) who studied the effect of commercial formulations of Bt (Agerin, Dipel 2X and Dipel DF) on larvae of $S$. littoralis. Obtained data were also similar to data obtained by Assar, et al. (2016) who found that the total protein content of $4^{\text {th }}$ instars of $S$. littoralis was decreased with all tested insecticides. The total protein was 30.3, 27.9 and 26.9 (mg/g.b.wt) with emamectin benzoate, hexaflumuron and teflubenzuron, respectively.

Table 2. Total proteins, total carbohydrates and total lipids activity in $4^{\text {th }}$ instar larvae of Spodoptera littoralis after treatment with Protecto, Viruset, Cascade, and Atabron.

\begin{tabular}{|c|c|c|c|}
\hline $\begin{array}{l}\text { Total Lipids } \\
\text { (gm./g b.w.) }\end{array}$ & $\begin{array}{l}\text { Total proteins } \\
(\mathrm{gm} . / \mathrm{g} \text { b.w.) } \\
\left(\text { Mean }^{\mathrm{a}} \pm \text { S.E) }\right.\end{array}$ & $\begin{array}{c}\text { Total carbohydrates } \\
(\text { gm./g b.w.) } \\
(\text { Mean } \pm \text { S.E) }\end{array}$ & $\begin{array}{c}\text { Tested } \\
\text { Compounds }\end{array}$ \\
\hline Protecto & $41.2 \pm 0.80^{b}$ & $48.6 \pm 1.5^{d}$ & $38.9 \pm 0.6^{b}$ \\
\hline Viruset & $40.06 \pm 0.6^{b}$ & $56.6 \pm 1.3^{c}$ & $38.36 \pm 0.79^{b}$ \\
\hline Cascade & $40.33 \pm 0.6^{b}$ & $69.63 \pm 0.6^{b}$ & $37.73 \pm 1.37^{b}$ \\
\hline Atabron & $39.36 \pm 0.39^{b}$ & $60.73 \pm 0.8^{c}$ & $39.06 \pm 0.475^{b}$ \\
\hline Control & $44.2 \pm 0.7^{a}$ & $75.7 \pm 2.05^{a}$ & $44.26 \pm 2.84^{a}$ \\
\hline
\end{tabular}




\section{REFERENCES}

1. Abd El-Salam, A.M.; Nemat, A.M. and Magdy, A. 2011. Potency of Bacillus thuringiensis and Bacillus subtilis against the cotton leafworm, Spodoptera littoralis (Boisd.) larvae. Archi. Phytopathol. Plant Protec., 44(3): 204-215.

2. Abdel-Aziz, M. M. 2012. Evaluating efficacy of certain bioagents and insect growth regulators against the cotton leaf worm, Spodoptera littoralis (Boisd.), using molecular technique. Ph. D. Thesis, Institute of Environmental Studies and Research, Ain Shams University. 166 Pp.

3. Abdel-Ghany, S.E. 2011. Assessment of environmental hazardous and molecular characterization of controlling of Spodoptera littoralis (Bosid) by some plant extracts. M. Sc. Thesis, Institute of Environmental Studies and Research, Ain Shams University

4. Abdel-Wahed, M. S.; Mariy, F. A.; Abdel-Aal, E. A. and Abdel-Aziz, M. M. 2011. The effect of certain biocontrol agent on same biological, biochemical and histological aspects of the cotton leaf worm, Spodoptera littoralis (Boisd.) (Lepidoptera: Noctuidae). Egypt. J. Agric. Res.; 89(2): 431-444.

5. Abou-Zeid, A. E. 1998. Physiological and toxicological effect of certain plant extracts on Osirinla nubilalis (Hubner). M.Sc. Thesis, Fac. of Science, Ain Shams Univ, Cairo, Egypt.

6. Anwar, E.M. and Abd El-Mageed, A.M. 2005. Toxicity impacts of certain insect growth regulators on some biochemical activities of the cotton leafworm, Egypt, J. Agric.Res., 87(2):915-935

7. Assar, A. A.; M. M. Abo El-Mahasen; H. F. Dahi; H.S. Amin. 2016. Biochemical effects of some insect growth regulators and bioinsecticides against cotton leaf worm, Spodoptera littoralis (Boisd.)(Lepidoptera: Noctuidae). J. Biosc. Appl. Res. 2, (8):587-594.

8. Bradford, M. M. 1976. A rapid and sensitive method for the quantitation of the microgram quantities of proteins utilizing the principles of protein-dye binding. Anal. Biochem., 72:248-25.

9. Crompton, M. and L. M. Birt. 1967. Changes in the amounts of carbohydrates. Phosphagen, and related compounds during the metamorphosis of the blowfly, Lucilia cuprina .J. Insect Physiol., 13:1575-1595.

10. Dent, D. 2000. Biological control. In: Insect Pest Management. $2^{\text {nd }}$ edition. London. CABI publishing. Ch. 6: 180-234 pp.

11. Dubios, M.; Gilles, K. A.; Hamilton, J. K.; Robers, P.A. and Smith F. 1956. Colorimetric method for determination of sugar and related substances. Analyt. Chem., 28: 350-356. 
12. Frank, R.; Braun, H. E.; Ripley, B. D. and Clegy, B. S. 1990. Contamination of rural ponds with pesticides, 1971-1985.Ontario, Canada Bull. Environm. Contamin. Toxicol. 13: 771-817.

13. Kamel, A. S.; M. F. Adel-Aziz; and N. M. El-Barky. 2010. Biochemical effects of three commercial formulations of Bacillus thuringiensis (Agerin, Dipel $2 \mathrm{X}$ and Dipel DF) on Spodoptera littoralis larvae. Egypt. Acad. J. biol. Sci., 3 (1): 21- 29.

14. Knight, J. A.; Anderson, S. and Rawle, J. M. 1972. Chemical basis of the sulfophospho-vanillin reaction for estimating total serum lipids. Clin. Chem., 18: 199-202.

15. Mabrouk, A. M. 2001. Interaction of nuclear polyhedrosis virus and $B$. thuringiensis to the cotton leaf worm, Spodoptera littoralis (Boisd.) (Lepidoptera: Noctuidae). Egypt. J. Bio. Pest Control, 11(2): 135-142.

16. Moscardi, F. 1999. Assessment of the application of baculoviruses for control of Lepidoptera. Ann. Rev. Entomol., 44: 257-289.

17. Shaurab, E.; Ahmed, Z. and El Naggar, S. 1998. Impacts of pyripraxyfen and extract of Schinus terebinthifolius (Raddi.) on development, reproduction and reproductive organs in Spodoptera littoralis (Boisd.). J. Egypt. Ger. Soc. Zool, vol. 27(E), 57-82.

18. Smagghe, G. and Degheele, D. 1992. Effect of nonsteroidal ecdysteroid agonist RH-5849 on reproduction of Spodoptera littoralis (Boisd.) (Lepidoptera: Noctuidae). Parasitica, 48: 23-29.

19. Smagghe, G.; Böhm, G.-A.; Richter, K.; and Degheele, D. 1995. Effects of nonsteroidal ecdysteroid agonists on the ecdysteroid titre in Spodoptera exigua and Leptinotarsa decemlineata. J. Insect Physiol. 41: 971-974.

20. Sundari, M.S. 1998. Inhibitor activity of Catharanthus roseus alkaloids on enzyme activity and reproduction in Euproctis fraternal (Lepidoptera: Lymantridae). Ann. Appl. Biol. 133:149:154

21. Tabashnik, B.E.; Finson, N. and Johnson, M.W. 1991. Managing resistance to Bacillus thuringiensis: Lessons from the diamondback moth (Lepidoptera: Plutellidae). Journal of economic entomology, 84(1): 49-55. 
1368 IMPACT OF SOME BIOAGENT AND INSECT GROWTH REGULATOR TO SOME BIOCHEMICAL ASPECTS OF THE COTTON LEAF WORM, SPODOPTERA LITTORALIS (BOISD.)

\title{
تأثير بعض المركبات الحيوية ومنظمات النمو الحشرية على بعض الجواتب البيوكيميائية لاودة ورق القطن
}

\author{
عادل حسن عبد السلام¹، آمال محمد مبروك 2 ، \\ هالة احمد كامل الصيرفى 1 ونيفين محمد فايز رزق 2
}

$$
\text { 2. } 1 \text { م جامعة المنصورة - كلية الزراعة - قسم الحشرات الاقتصادية. }
$$

تم إجراء هذه التجربة على يرقات العمر الرابع لدودة ورق القطن باستخدام مركبات

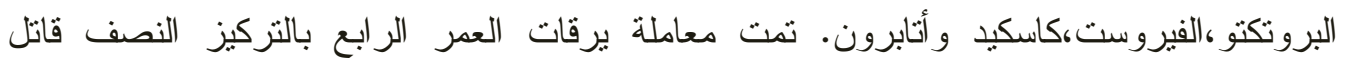

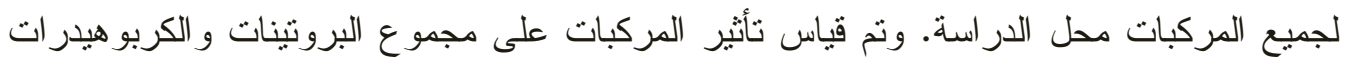

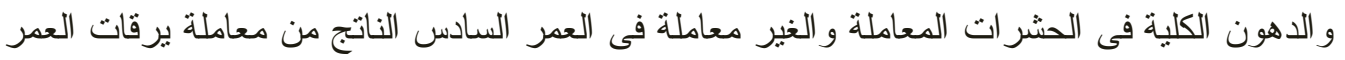

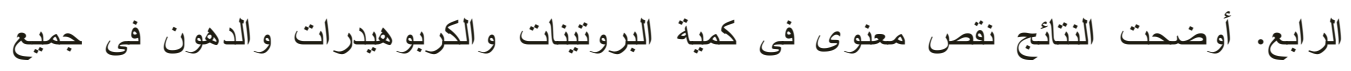

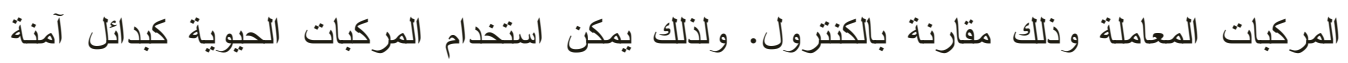

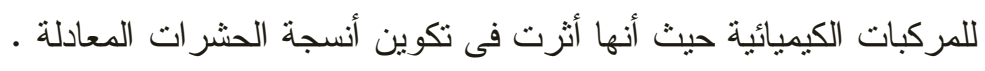

